The current issue and full text archive of this journal is available on IHTIFAZ at :

https://doi.org/10.12928/ijiefb.v2i2.857

\title{
Persepsi, Sikap dan Minat Pariwisata Halal di Daerah Istimewa Yogyakarta
}

\author{
Firdausa Kumala Sari ${ }^{1 *}$, Novita Safitri ${ }^{1}$, Wahyu Anggraini ${ }^{1}$ \\ ${ }^{1}$ Universitas Islam Negeri Sunan Kalijaga Yogyakarta, Indonesia \\ *e-mail: firdausakumalasari9@gmail.com
}

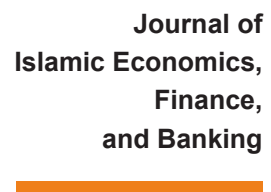

Vol. 2, No. 2, Desember 2019.

\begin{abstract}
This study aims to examine the Theory of Planned Behavior (TPB) regarding pp. 137-155, ISSN p:2622-4755 the influence of perceptions of concepts on attitudes, perceptions of development towards attitudes, and attitudes towards the interests of the DIY community regarding halal tourism. The design of this study was descriptive and correlational involving 435 subjects of the Yogyakarta Special Region, collecting data through surveys by filling in questionnaires. The influence of perception, attitudes towards the interests of the DIY community regarding halal tourism were tested using data analysis techniques with CB-SEM (Covariance Based-Structural Equation Modelling) with Amos Software. The findings show that there is an influence between perceptions and attitudes towards people's interest in halal tourism. The public perception of halal tourism lies in its facilities. Facility criteria are included in one of the GMTI (Global Muslim Travel Index) criteria. The government is expected to prioritize the development of halal tourism facilities.
\end{abstract}

Keywords: Perception, Attitude, Intention, Halal Tourism

\begin{abstract}
ABSTRAK
Penelitian ini bertujuan untuk menguji Theory of Planned Behavior (TPB) mengenai pengaruh persepsi konsep pada sikap, persepsi perkembangan pada sikap, dan sikap pada minat masyarakat DIY tentang pariwisata halal. Rancangan penelitian ini deskriptif dan korelasional yang melibatkan 435 subyek dari Daerah Istimewa Yogyakarta, mengumpulkan data melalui survei dengan mengisi kuesioner. Pengaruh persepsi konsep pada sikap DIY tentang pariwisata halal diuji menggunakan teknik analisis data dengan SB-SEM (Covariance Based-Structural Equation Modelling) dengan softwere AMOS. Penelitian ini menunjukkan bahwa ada pengaruh anatara persepsi dan sikap pada minat masyarakat dalam pariwisata halal. Persepsi masyarakat tentang pariwisata halal terletak pada fasilitasnya. Kriteria fasilitas termasuk dalam salah satu kriteria GMTI (Global Muslim Travel Index). Pemerintah diharapkan memprioritaskan pengembangan fasilitas wisata halal.
\end{abstract}

Kata Kunci: Persepsi, Sikap, Minat, dan Pariwisata Halal

Ihtifaz: Journal of Islamic Economics, Finance, and Banking 


\section{PENDAHULUAN}

Pariwisata Indonesia mendapat kepercayaan dunia, Indonesia IHTIFAZ - JIEFB dinobatkan sebagai 10 besar destinasi terbaik versi Lonely Planet (2019:5). Lembaga ini memproyeksi Indonesia sebagai salah satu negara terbaik untuk dikunjungi pada tahun 2019. Indonesia satusatunya negara ASEAN yang masuk dalam daftar 10 besar. Menurut Lonely Planet dengan lebih dari 17.000 pulau dengan keragaman budaya, kuliner, dan agama, Indonesia menawarkan kaleidoskop pengalaman.

Salah satu industri pariwisata yang semakin berkembang adalah industri pariwisata halal. Industri pariwisata halal telah populer sejak tahun 2016, menurut UNWTO (2016), muslim traveler memiliki pengeluaran terbesar dunia pada sektor pariwisata, yang besarnya mencapai US\$ 120 miliar pada 2015. Tahun 2016 Mastercard-Crescent Rating meluncurkan hasil studi Global Muslim Travel Index (GMTI). Studi tahun 2016, Indonesia berada di peringkat kedua sebagai destinasi wisata halal populer di dunia. Tahun 2018 pertumbuhan wisatawan muslim meningkat hingga 6,3\%. Indonesia menempati peringkat keempat sebagai negara dengan turis muslim terbesar dengan pengeluaran mencapai US $\$ 9,7$ miliar atau setara dengan Rp 141 triliun, dengan total turis domestik sebesar 200 juta orang. Selain itu, saat ini Indonesia telah masuk dalam kategori Top 5 Destinasi Pariwisata Halal Dunia, dengan penerimaan devisa negara mencapai US\$13 miliar, yang berkontribusi terhadap PDB sebesar US\$ 57,9 miliar. Pada 2020, sektor pariwisata diproyeksikan menjadi kontributor terbesar bagi penerimaan devisa negara.

Fazal Bahardeen, CEO Crescent Rating \& Halal Trip mengatakan, dengan posisi Indonesia sebagai negara muslim terbesar di dunia, wawasan IMTI 2018 akan memungkinkan daerah-daerah di Indonesia untuk membangun kekuatan mereka sehingga dapat memenuhi kebutuhan wisatawan muslim dengan lebih baik (Anonim, 2018). Salah satu daerah yang berpotensi dijadikan industri pariwisata syariah adalah DIY (Daerah Istimewa Yogyakarta) karena berdasarkan informasi dari hasil Kajian Data Pasar Wisatawan Nusantara Tahun 2016, DIY termasuk ke dalam 10 besar daerah yang memiliki pengunjung terbanyak menurut destinasi. Bahkan dalam kurun waktu 2013-2017 pariwisata DIY semakin meningkat. Tahun 2013 terdapat 2.837.907 wisatawan dan terus meningkat pada tahun 2017 terdapat 5.229.298 wisatawan. 

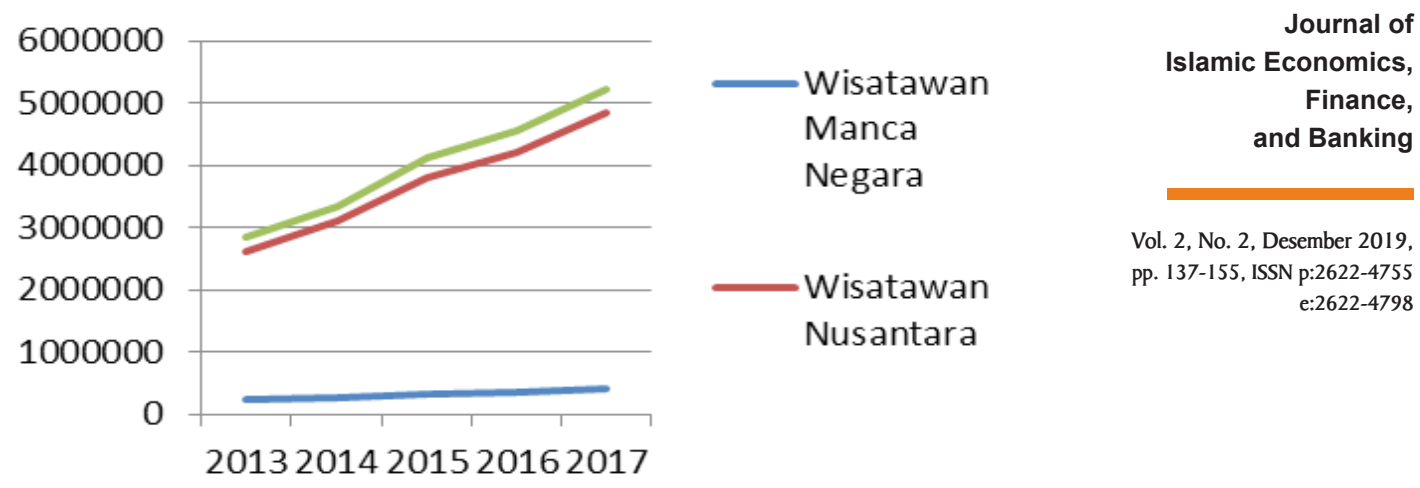

Sumber: Statistik Kepariwisataan 2017, Dinas Pariwisata

Gambar 1. Grafik Perkembangan Wisatawan ke DIY Tahun 2013-2017

Dalam berita yang dimuat di situs ekonomisyariah.org (Anonim, 2017) Ketua MES (Masyarakat Ekonomi Syariah), Muliaman D Hadad, meminta MES untuk mengajak para pelaku usaha maupun masyarakat untuk menjadikan beberapa kota di DIY sebagai kota pariwisata berbasis syariah karena pariwisata ini akan memiliki dampak ekonomi yang besar bagi para pelaku usaha dan masyarakat di DIY. Dengan pengembangan wisata syariah yang berkelanjutan akan meningkatkan kontribusi ekonomi bagi pelaku bisnis yang ada di dalam industri pariwisata syariah atau pariwisata halal. Selain itu, sesuai dengan yang disampaikan oleh mantan presiden Indonesia Susilo Bambang Yudhoyono pada saat peluncuran Gerakan Ekonomi Syariah (GRES) di kawasan silang Monas, tanggal 17 November 2013 keberadaan ekonomi syariah memiliki banyak manfaat untuk mengurangi kerentanan antara sistem keuangan dengan sektor riil untuk menghindari penggelembungan ekonomi; menghindari pembiayaan yang cenderung berubah, dan dapat memperkuat keamanan masyarakat.

Untuk mencapai hal tersebut perlu adanya dukungan dari masyarakat karena salah satu faktor permintaan yaitu adanya minat/selera masyarakat akan suatu barang jasa (Karim, 2001:83). Semakin tinggi minat masyarakat akan suatu barang dan jasa, semakin tinggi pula permintaan atas barang dan jasa tersebut. Jika permintaan akan barang dan jasa tinggi, maka akan menyebabkan meningkatnya pertumbuhan ekonomi.

Maka dari itu perlu diketahui penyebab konsumen memiliki minat/ selera dalam mengkonsumsi barang. Dalam Modified Theory of Planned Behavior yang dikemukaan oleh Ajzen (2005:179) menyatakan bahwa perilaku seseorang akan dipengaruhi oleh minat; minat berperilaku akan dipengaruhi oleh sikap, norma subyektif dan persepsi kontrol keperilakuan; sikap dipengaruhi oleh faktor-faktor latar belakang individu. Sebagaimana dikatakan oleh Ajzen (1991:198) bahwa TPB cocok untuk menjelaskan perilaku apa pun yang memerlukan perencanaan, seperti kewirausahaan. 
Dalam hal pengembangan pariwisata halal di DIY, perlu adanya uji mengenai teori tersebut apakah akan relevan jika diterapkan pada IHTIFAZ - JIEFB masyarakat DIY. Oleh karena itu, digunakan Metode SEM (Structural Equation Modeling) karena Metode SEM cocok untuk membuktian teori tersebut. Metode SEM memiliki keunggulan dibandingkan regresi, karena dapat menganalisis beberapa hubungan pada satu waktu atau dapat menguji beberapa variabel dependen (endogen) melalui beberapa variabel independen (eksogen). SEM dapat dikatakan sebagai kombinasi antara analisis faktor dan analisis regresi berganda. Selain itu, SEM sering disebut sebagai Path Analysis atau Confirmatory Factor Analysis karena perlu justifikasi teoritis atau proses nalar yang kuat untuk mengkonfirmasi apakah indikator yang digunakan harus mempunyai pijakan teori sehingga dapat mengkonfirmasi konstruk/variabelnya (Minto, 2016:6).

SEM terbagi menjadi dua jenis tipe, yaitu PLS-SEM (Partial Least Square SEM) dan CB-SEM (Covariance Based SEM). Tipe yang cocok untuk digunakan dalam penelitian ini adalah CB-SEM. Karena pendekatan dalam penelitian ini berdasarkan covarience, metode yang digunakan Likelihood, dan mensyaratkan data terdistribusi normal serta memenuhi criteria goodness of fit sebelum estimasi parameter (Reinartz et al., 2009). Alat yang cocok untuk mengolah data dengan tipe CB-SEM, yakni software Amos karena Amos mampu menjawab masalah yang bersifat korelasi regresif dan dapat mengidentifikasi dimensi sebuah konsep (Ginting, 2009:121).

Jika hasil pengolahan data teruji signifikan, yakni persepsi mempengaruhi sikap dan sikap mempengaruh minat, maka diperlukan pengembangan model/konsep pariwisata halal yang cocok dengan indikator mengenai persepsi (Persepsi Konsep dan Persepsi Pengembangan) pariwisata halal. Selain itu, indikator pengembangan pariwisata halal harus sesuai dengan plot GMTI, karena Kemenpar dan MUI sepakat mengembangkan pariwisata halal dengan menggunakan kriteria GMTI sebagai acuannya (Lampungnews, 2019). Dalam acuan GMTI ada tiga kelompok kriteria wisata halal yang diulas. Pertama, destinasi ramah keluarga yang mencakup keamanan umum bagi wisatawan muslim serta jumlah kedatangan wisatawan muslim. Kedua, layanan dan fasilitas di destinasi yang ramah muslim. Ketiga, kesadaran halal dan pemasaran destinasi. (Sindonews, 2016).

\section{TINJAUAN PUSTAKA}

\section{Pariwisata Halal}

Menurut Pleanggra (2012) pariwisata adalah kegiatan melakukan perjalanan dengan tujuan untuk mendapatkan kepuasan, menghilangkan rasa penat, memperbaiki kesehatan, berziarah, maupun memenuhi suatu tugas. Adapun jika berbicara mengenai istilah halal dalam bahasa hukum syariah Islam halal berarti "diperbolehkan" (Battour dalam Manara, 2018). 
Alim et.al (t.t) berpendapat bahwa pariwisata halal selalu mengedepankan nilai-nilai keislamam dalam segala aktivitasnya. Wisata halal merupakan salah satu upaya Kementerian Pariwisata dan Ekonomi Kreatif (Kemenparekraf) dalam mewujudkan wisata syariah di Indonesia. Pada peluncuran wisata syariah yang bertepatan dengan kegiatan Indonesia Halal Expo (Index) 2013 dan Global Halal Forum yang digelar pada 30 Oktober - 2 November 2013 di Semeru Room, Lantai

Journal of Islamic Economics, Finance, and Banking Vol. 2, No. 2, Desember 2019 , pp. 137-155, ISSN p:2622-4755 6, Gedung Pusat Niaga, JIExpo (PRJ), Kemayoran, Jakarta Pusat, Rabu (30/10/2013), President Islamic Nutrition Council of America, Muhammad Munir Caudry, menyampaikan bahwa, "Wisata halal merupakan konsep baru pariwisata. Ini bukanlah wisata religi seperti umroh dan menunaikan ibadah haji. Wisata halal adalah pariwisata yang melayani liburan, dengan menyesuaikan gaya liburan sesuai dengan kebutuhan dan permintaan traveler muslim" (Wuryasti, 2013).

Wisata halal bukan merupakan wisata yang ekslusif karena orang muslim maupun non-muslim dapat menikmati pelayanan berdasarkan nilai-nilai halal. Wisata halal tidak hanya meliputi destinasi ziarah dan religi, tetapi juga mencakup ketersediaan fasilitas pendukung, seperti restoran dan hotel yang menyediakan makanan halal dan tempat salat (Adriani, 2015).

\section{PARADIGMA THEORY OF PLANED BEHAVIOR (TPB), PERSEPSI, SIKAP, dan MINAT}

Teori yang menjadi dasar perilaku konsumen dikemukakan oleh Ajzen dan Fishbein (1975). Ajzen dan Fishbein (1975) mengajukan The Theory of Reasoned Action (TRA). TRA menunjukkan bahwa perilaku seseorang akan dipengaruhi oleh minat, dan minat akan dipengaruhi oleh sikap. TPB merupakan pengembangan lebih lanjut dari TRA (Riza, 2017). TPB menyatakan bahwa sikap terhadap perilaku, norma subyektif, dan kontrol perilaku yang dipersepsikan, bersama-sama membentuk niat dan perilaku perilaku individu (Azjen, 2005:179).

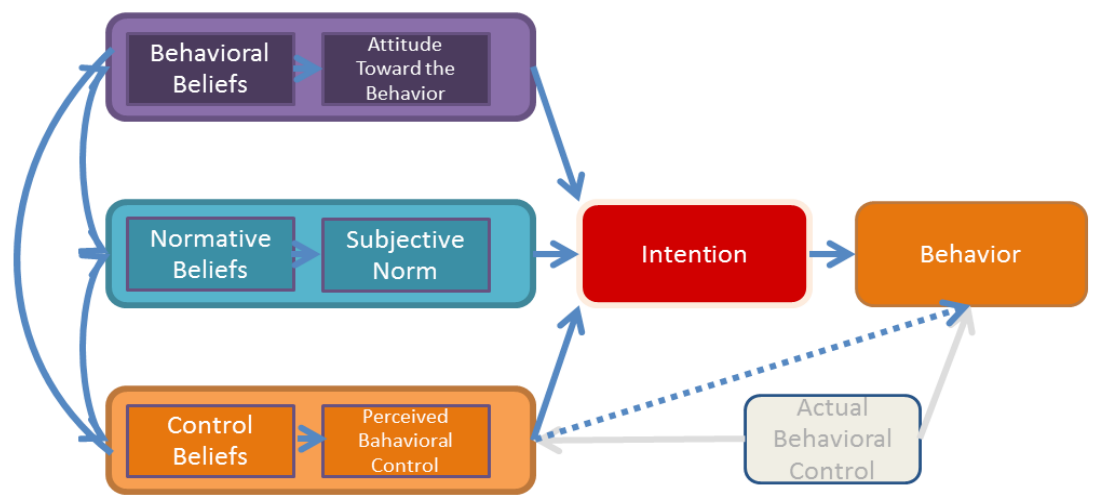

Sumber: Ajzen, I. (2005). Organizational Behavior and Human Decision Processes, 50, p. 179-211.

Gambar 2. Modified Theory of Planned Behavior 
TPB menambahkan konsep persepsi pengendalian perilaku, yang berasal dari teori Self-Efficacy Theory (SET). SET adalah prasyarat yang paling penting untuk perubahan perilaku, karena menentukan inisiasi perilaku koping. Teori self- efficacy memberikan kontribusi untuk menjelaskan berbagai hubungan antara keyakinan, sikap, niat, dan perilaku (Azjen, 2005: 184).

Ajzen kemudian mengembangkan TPB menjadi Modified TPB atau teori perilaku terencana modifikasi. Faktor individu seperti personal, sosial dan informasi yang mempengaruhi sikap dan perilaku individu. CB-SEM dianggap tepat untuk memprediksi perilaku Modified TPB menunjukkan bahwa perilaku seseorang akan dipengaruhi oleh minat; minat berperilaku akan dipengaruhi oleh sikap, norma subyektif dan persepsi kontrol keperilakuan; sikap dipengaruhi oleh faktor-faktor latar belakang individu.

\section{Persepsi}

Secara umum persepsi merupakan proses perolehan, penafsiran, pemilihan dan pengaturan informasi indrawi menggunakan alat panca indra (Sarwono, 2009). Persepsi merupakan suatu proses yang membuat seseorang untuk memilih, mengorganisasikan dan menginterprestasikan rangsangan-rangsangan yang diterima menjadi suatu gambaran yang berarti dan lengkap tentang dunianya (Wahyuni, 2008). Persepsi pada hakikatnya adalah proses kognitif yang dialami oleh setiap orang dalam memahami informasi tentang lingkungannya, merupakan suatu penafsiran yang unik terhadap situasi (Oktradiksa, 2015). Cara pandang akan menentukan kesan yang dihasilkan dari proses persepsi. Persepsi masyarakat akan menghasilkan suatu penilaian terhadap sikap (Listyana, 2015). Persepsi menandakan adanya pandangan dari setiap orang terhadap sesuatu baik kondisi, keadaan atau suasana.

\section{Sikap}

Sikap merupakan suatu disposisi untuk merespon secara positif atau negatif perilaku tertentu (Ajzen, 1991). Sikap sebagai suatu evaluasi yang menyeluruh dan memungkinkan seseorang untuk merespon dengan cara yang menguntungkan atau tidak terhadap obyek yang dinilai (Wahyuni, 2008). Sikap merupakan reaksi mengenai objek atau situasi yang relatif stagnan yang disertai dengan adanya perasaan tertentu dan memberi dasar pada orang tersebut untuk membuat respon atau perilaku dengan cara tertentu yang dipilihnya (Mulyana, 2013). Sikap menurut Sunaryo dalam Febriyanto (2016) adalah kecenderungan individu untuk bertindak berupa respon tertutup terhadap stimulus ataupun objek tertentu. Di mana dalam hal sikap, dapat dibagi menjadi menerima, merespon, menghargai, dan bertanggung jawab (Notoatmodjo dalam Febriyanto, 2016). Sebuah evaluasi konsep yang dilakukan oleh seseorang merupakan konsep, yang mana evaluasi dapat 
diciptakan oleh sistem afektif maupun kognitif (Peter dan Olson dalam Divianjella, 2018). Sikap berimplikasi pada sesuatu tindakan yang sesuai dengan kondisi atau keadaan seseorang.

\section{Minat}

Minat adalah suatu perhatian yang kuat dan mendalam serta perasaan

Vol. 2, No. 2, Desember 2019 senang seseorang terhadap suatu kegiatan sehingga mengarahkannya pp. 137-155, ISSN p:2622-4755 untuk melakukan kegiatan tersebut atas dasar kemauan sendiri (Lilawati dalam Zusnani, 2013). Minat merupakan kecenderungan jiwa seseorang kepada sesuatu (biasanya disertai dengan perasaan senang), karena merasa ada kepentingan dengan sesuatu itu (Mulyana, 2013). Minat seseorang timbul dari dalam diri orang tersebut tanpa adanya orang lain yang menyuruh (Nurkhan, 2005). Adapun minat meliputi dua aspek, yaitu aspek kognitif berdasarkan konsep yang dikembangkan dengan bidang yang berkaitan dengan minat dan aspek afektif yang membangun aspek kognitif serta dinyatakan dalam sikap terhadap kegiatan yang dapat menimbulkan minat (Kambuaya, 2015). Minat berawal dari keinginan untuk berbuat sesuatu sesuai dengan apa yang dikehendaki.

\section{PENGEMBANGAN HIPOTESIS}

Pemahaman saat ini tentang faktor-faktor apa yang mempengaruhi penggunaan User Generated Content (UGC) ketika wisatawan membuat rencana perjalanan dalam penelitian Filho et. al (2009) menggunakan TPB mengusulkan model konseptual perilaku konsumen online yang bertujuan untuk mendapatkan pemahaman yang lebih baik tentang bagaimana sikap, norma subyektif, dan kontrol perilaku yang dirasakan, bekerja sama untuk menentukan perilaku konsumen online, lebih khusus penggunaan UGC saat membuat rencana perjalanan.

H1: Persepsi konsep berpengaruh positif terhadap sikap masyarakat akan pariwisata halal.

Keyakinan tentang keberadaan faktor-faktor yang dapat memfasilitasi atau menghambat kinerja perilaku (keyakinan kontrol) mempertimbangkan bagaimana sikap manusia (Ajzen, 2019). Kontrol keyakinan menimbulkan persepsi kontrol perilaku yang akan mempengaruhi sikap.

H2: Persepsi Pengembangan berpengaruh positif terhadap sikap masyarakat akan pariwisata halal.

Menurut Theory Planned Behavior minat dipengaruhi oleh tiga variabel, yaitu sikap, norma subjektif dan persepsi kontrol perilaku. Teori tersebut dibuktikan dalam penelitian yang dilakukan oleh Susanti et. al (2018), hasil penelitiannya menunjukkan bahwa sikap positif dan signifikan terhadap minat.

H3:Sikap berpengaruh positif terhadap minat masyarakat akan pariwisata halal. 


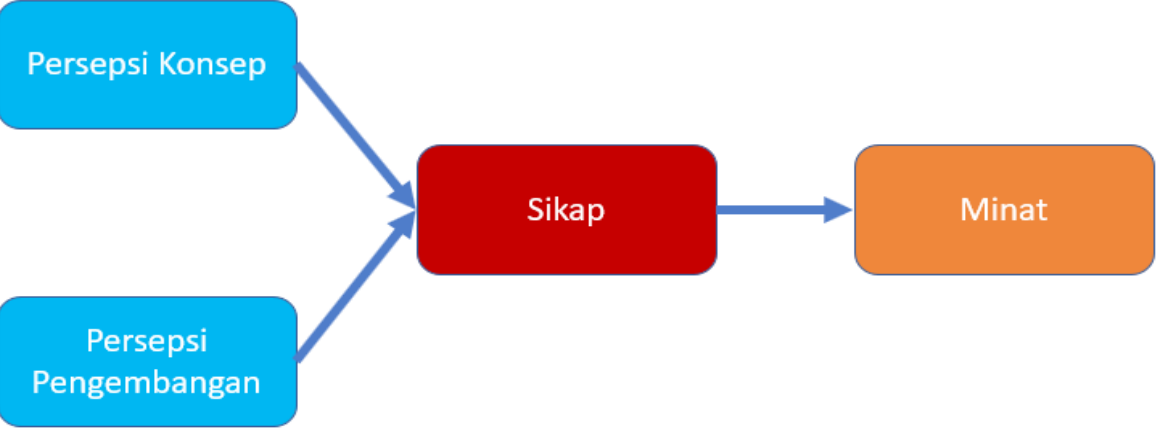

Gambar 3. Model Penelitian/Kerangka Berpikir

Peneliti akan menganalisis apakah persepsi berpengaruh terhadap sikap dan sikap berpengaruh terhadap minat masyarakat untuk mengunjungi pariwisata halal. Jika demikian, maka perlu diketahui persepsi seperti apakah yang berkembang di masyarakat DIY. Melalui analisis pengolahan data tersebut akan dihasilkan kesimpulan terkait tingkat pengaruh persepsi pariwisata halal setiap individu terhadap minat berwisata halal. Ketika hasil dapat menunjukkan angka positif maka perwujudan wisata halal di DIY perlu ditingkatkan sesuai dengan kebutuhan dan permintaan calon wisatawan.

\section{METODOLOGI PENULISAN}

\section{Populasi dan Sampel}

Populasi dalam penelitian ini adalah seluruh masyarakat DIY. Sampel dalam penelitian ini adalah responden di lima kabupaten/kota yang ada di DIY yaitu kabupaten Kota Yogyakarta (80 responden), Sleman (127 responden), Bantul (97 responden), Gunung Kidul (69 responden), dan Kulon Progo (62 responden).

Teknik pengambilan sampel yang digunakan adalah cluster random sampling (Sudrajat, 2009: 125) menjelaskan bahwa cluster random sampling adalah pengambilan sampel secara random yang bukan individual, tetapi kelompok-kelompok unit yang kecil. Cluster di sini dikelompokkan dalam usia, gender, penghasilan, dan pendidikan terakhir.

\section{Metode Pengumpulan Data}

Metode pengumpulan data yang digunakan peneliti adalah survei melalui pengisian kuesioner, survei merupakan pemeriksaan secara teliti tentang fakta atau fenomena perilaku dan sosial terhadap subyek dalam jumlah besar (Ali, 2010). Sedangkan pengumpulan data melalui studi pustaka dilakukan dengan menelusuri dan mempelajari informasi atau teori yang berkaitan dengan tema yang dikaji peneliti melalui buku, jurnal, dan penelitian yang sudah ada. 
Indikator dalam kuisioner diambil dari berbagai sumber yang sudah ada, di antaranya indikator untuk persepsi konsep berdasarkan indikator yang digunakan dalam laporan GMTI (Mastercard dan Crescentrating, 2018).

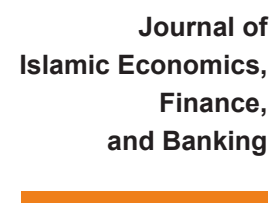

Vol. 2, No. 2, Desember 2019. pp. 137-155, ISSN p:2622-4755 e:2622-4798

Variabel satu Perspsi Konsep diukur menggunakan instrumen penelitian dengan indikator: aktifitas, fasilitas, akses, dan pelayanan. Diukur menggunakan skala antara 1 sampai 4, dengan rincian jawaban Sangat Tidak Setuju (STS=1), Tidak Setuju (TS=2), Setuju $(S=3)$, dan Sangat Setuju (SS=4). Variabel dua Persepsi Pengembangan menggunakan instrument penelitian dengan indikator: pengembangan ekonomi, pengembangan budaya dan pengembangan sosial. Diukur menggunakan skala penilaian antara 1 sampai 4 . Variabel tiga menggunakan instrumen penelitian dengan indikator: sikap mengenai tujuan, pilihan, urgensi, dan ekspektasi terhadap pariwisata halal. Diukur menggunakan skala penilaian antara 1 sampai 4. Variabel empat menggunakan instrumen penelitian dengan indikator: minat secara kognitif, afektif, dan behavior. Diukur menggunakan skala penilaian antara 1 sampai 4.

\section{Teknik Analisis Data}

SEM adalah suatu teknik analisis beberapa/satu variabel independen dan beberapa/satu variabel dependen yang tidak mampu dianalisis menggunakan regresi sederhana maupun berganda (Awwal et al., 2018:65). Sementara aplikasi program yang digunakan untuk analisis SEM dalam penelitian ini adalah AMOS (Analysis Of Moment Structure). AMOS berguna untuk menganalisis hubungan kausalitas dalam model structural yang diusulkan.

SEM merupakan teknik analisis yang memungkinkan pengujian sebuah rangkaian hubungan secara simultan. Hubungan ini dibangun antara satu atau beberapa variabel independen dengan satu atau beberapa variabel dependen. SEM merupakan pendekatan terintegrasi antara dua analisis yaitu analisis faktor dan jalur (path analysis).

\section{Uji Reliabilitas dan Uji Validitas}

Uji reliabilitas merupakan pengujian untuk mengetahui tingkat konsistensi suatu pengukuran, di mana pandangan atau jawaban antar responden konsisten (stabil) dari waktu ke waktu. Dengan kata lain, jawaban tersebut tidak mengandung perbedaan yang signifikan antara responden satu dengan yang lainnya (Awwal et.al., 2018;69). Dengan cronbach's alpha di atas 0.6. Uji validitas merupakan pengujian untuk mengetahui kevalidan (tingkat ketepatan) pertanyaan yang diajukan dengan keadaan yang seharusnya terkait objek yang diteliti Melalui pengujian ini akan diketahui apakah indikator pertanyaan yang 
disampaikan sesuai dengan keadaan umumnya atau tidak (Awwal et al., 2018;69). Dengan kriteria nilai factor loading setiap butir indikator

\section{Uji Asumsi}

Setelah dilakukan uji reliabilitas dan uji validitas, selanjutnya dilakukan uji terhadap asumsi-asumsi yang dipersyaratkan dalam SEM, yaitu Uji Kecukupan Sampel, untuk model SEM dengan jumlah variabel laten sampai dengan empat buah dan setiap konstruk dijelaskan oleh satu atau lebih indikator, maka jumlah sampel 100-150 data sudah dianggap memadai (Santoso, 2011).

Uji Normalitas, adalah pengujian untuk mengetahui apakah data yang digunakan mempunyai distribusi normal. Dalam output AMOS, uji normalitas dilakukan dengan membandingkan nilai c.r (critical ratio) pada assessment of normality dengan kritis $\pm 2,58$ pada level 0,01. Jika nilai c.r lebih besar dari nilai kritis maka distribusi data tersebut tidak normal secara univariate. (Ferdinand, 2006:11).

Uji Outlier, adalah kondisi data pada suatu penelitian yang memiliki karakteristik unik yang terlihat sangat berbeda jauh dari data penelitian lainnya dan muncul dalam bentuk nilai ekstrim baik dalam variabel tunggal maupun variabel kombinasi. Data penelitian dikatakan outlier jika nilai $\mathrm{df}>4$.

Uji Model atau Goodness of Fit, merupakan uji kelayakan suatu model dengan beberapa kriteria kesesuaian indeks dan cut off valuenya, untuk menunjukkan seberapa baik model yang diturunkan menghasilkan kembali matrix cofarian diantara variabel-variabel indikator (Hair et al., 2010:664).

Uji Hipotesis, menjelaskan langkah-langkah analisis yang digunakan dalam penelitian ini. Langkah-langkah tersebut mengacu pada 7 langkah proses analisi SEM menurut Hair et al (Hair et al., 2010:661). Urutan dan pembahasannya yaitu: pengembangan model berdasarkan teori, menyusun diagram alur (path diagram), konversi diagram alur ke dalam persamaan struktural, input matriks dan estimasi model, identifikasi model struktural, menilai kriterian goodness of fit, dan interpretasi dan modifikasi model.

\section{HASIL DAN PEMBAHASAN}

\section{Karakteristik Responden}

Dari 435 responden dalam penelitian ini data yang bisa digunakan sebesar 335, dimana responden dalam penelitian ini adalah 335 masyarakat yang tersebar di DIY. Tabel 1 di bawah menunjukkan bahwa responden tersebar di berbagai kalangan masyarakat, bahwasannya mayoritas responden berjenis kelamin perempuan $(55,8 \%)$, status mayoritas belum menikah $(59,1 \%)$, pendidikan terakhir mayoritas 
SMA/Sederajat $(59,4 \%)$, usia mayoritas $18-25$ tahun $(52.2 \%)$, dan pendapatan mayoritas kurang dari Rp10.000.000/tahun (73,1\%).

Tabel 1. Informasi Demografi Responden
Journal of

Islamic Economics,

Finance,

and Banking

Vol. 2, No. 2, Desember 2019 , pp. 137-155, ISSN p:2622-4755

\section{Jenis Kelamin}

Perempuan

187

55,8

Laki - laki

148

44,2

\section{Status Pernikahan}

Menikah

$\begin{array}{rr}131 & 39,1 \\ 198 & 59,1 \\ 0 & 0 \\ 6 & 1,8\end{array}$

Belum Menikah

Cerai Hidup

1,8

\section{Pendidikan Terakhir}

SMP/Sederajat

$\begin{array}{rr}42 & 12,5 \\ 199 & 59,4 \\ 28 & 8,4 \\ 51 & 15,2 \\ 12 & 3,6 \\ 1 & 0,3 \\ 2 & 0,6\end{array}$

SMA/Sederajat

$(2,5$

Diplomasi I/II/III

8,4

S1

15,2

SD

Profesi

0,3

S2

0,6

\section{Usia (tahun)}

$18-\leq 25$

185

52.2

$25-\leq 30$

39

11,6

$30-\leq 35$

25

7,5

Lebih dari 35

86

25,7

\section{Pendapatan/tahun}

Kurang dari Rp10.000.000,00

$245 \quad 73,1$

Rp10.000.001,00- Rp50.000.000,00

Rp50.000.001,00- Rp100.000.000,00

$74 \quad 22,1$

Rp100.000.001,00- Rp250.000.000,00

$7 \quad 2,1$

Rp50.000.001,00- Rp500.000.000,00

$6 \quad 1,8$

Lebih dari Rp500.000.000,00

0

$3 \quad 0,9$

\section{Uji Statistik Deskriptif Variabel}

Nilai tanggapan rata-rata variabel persepsi konsep yaitu 3,6597 yang mendekati nilai maksimum 4,00, hal ini menunjukkan respon masyarakat 
setuju mengenai persepsi konsep. Nilai tanggapan rata-rata variabel persepsi pengembangan yaitu 3,4731 yang mendekati nilai maksimum IHTIFAZ - JIEFB 4,00 , hal ini menunjukkan respon masyarakat setuju mengenai persepsi pengembangan. Nilai tanggapan rata-rata variabel minat yaitu 3,3970 yang mendekati nilai maksimum 4,00, hal ini menunjukkan respon masyarakat setuju mengenai minat. Nilai tanggapan rata-rata variabel sikap yaitu 3,3970 yang mendekati nilai maksimum 4,00, hal ini menunjukkan respon masyarakat setuju mengenai sikap.

\section{Uji Reliabilitas dan Uji Validitas}

Hasil uji reliabilitas yang dalam penelitian ini yaitu, persepsi konsep 0,956, persepsi pengembangan 0,789, minat 0,906, dan sikap 0,960. Dari hasil penelitian menunjukkan bahwa konstruk yang diukur adalah reliabel karena semua konstruk memiliki nilai cronbach's alpha di atas 0.6. Oleh karena itu dapat dikatakan bahwa seluruh variabel dalam penelitian ini memiliki reliabilitas yang baik dan dapat digunakan dalam tahap analisis selanjutnya.

Uji validitas dalam penelitian menggunakan content validity yaitu pengukuran yang mewakili semua aspek definisi konseptual dari sebuah konstruk (Numan, 2006:193). Peneliti menggunakan confirmatory factor analiysis dengan kriteria nilai factor loading setiap butir indikator nilainya $\geq 0,5$ yang diuji menggunakan software SPSS 20 untuk menguji validitas ini.

Tabel 2 menunjukkan bahwa uji validitas dalam penelitian ini terpenuhi, karena nilai factor loading setiap butir indikator $\geq 0,5$.

Tabel 2. Hasil Uji Validitas

\begin{tabular}{lcccc}
\hline & \multicolumn{4}{c}{ Component } \\
& $\mathbf{1}$ & $\mathbf{2}$ & $\mathbf{3}$ & $\mathbf{4}$ \\
\hline PK6 & 0,805 & & \\
PK7 & 0,802 & & \\
PK8 & 0,830 & & \\
PK9 & 0,854 & & \\
PK10 & 0,784 & & \\
PK11 & 0,818 & & \\
PK13 & 0,599 & & \\
PK15 & 0,521 & & \\
PP1 & & 0,769 \\
PP2 & & 0,797 \\
PP3 & & 0,782
\end{tabular}




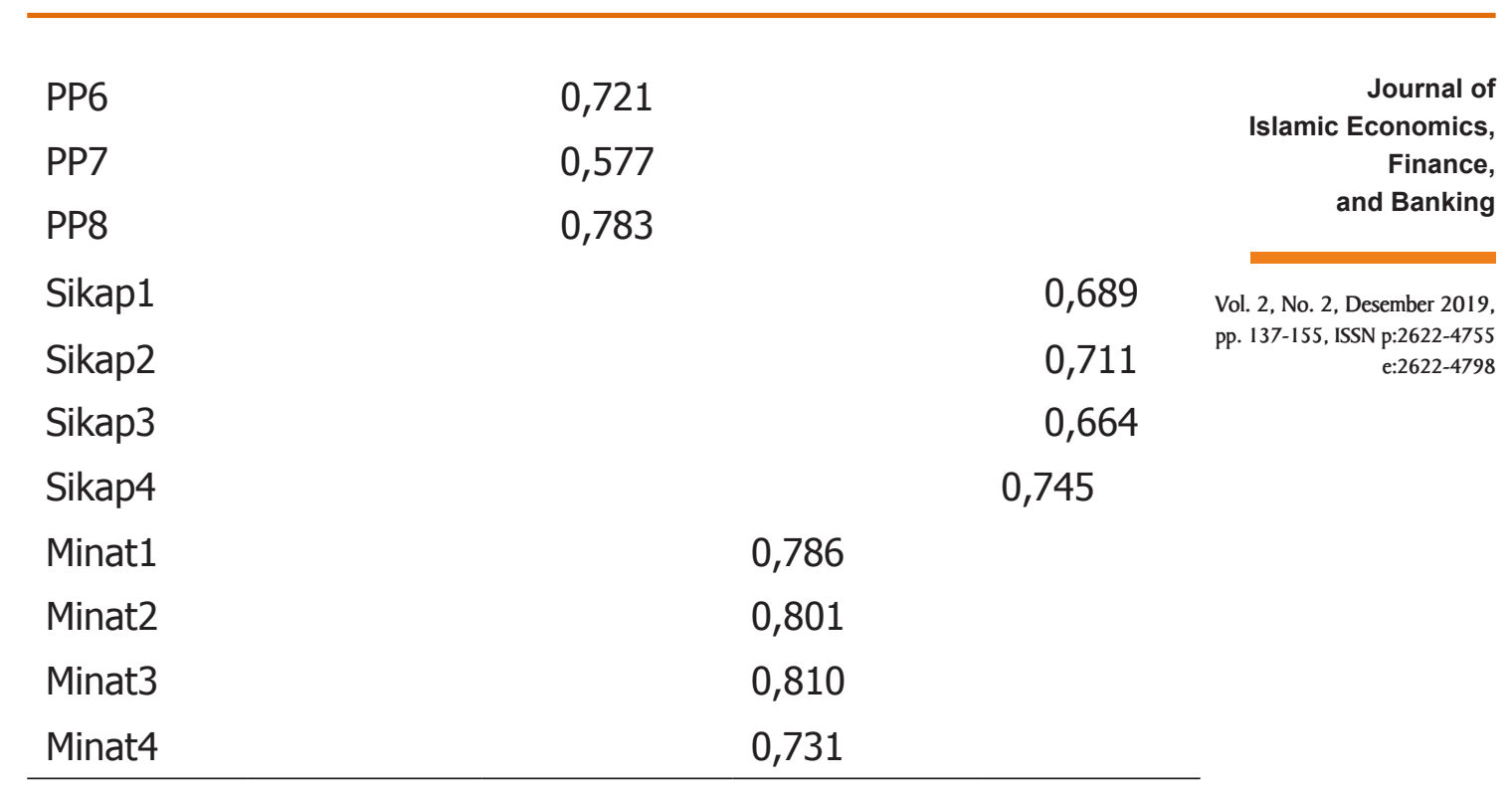

\section{Uji Asumsi}

\section{Uji Kecukupan Sampel}

Sampel awal dalam penelitian ini berjumlah 435, namun yang bisa digunakan berjumlah 335 . Hal ini menunjukkan uji kecukupan sampel terpenuhi, karena jumlah sampel lebih dari 100-150 data.

\section{Uji Normalitas}

Uji normalitas dilakukan dengan membandingkan nilai C.R (critical ratio) pada assessment of normality dengan nilai $C R \leq 2.58$ pada nilai signifikan di bawah 0.05 atau pada nilai signifikan $\leq 1.91$ pada nilai signifikan di bawah 0.01 . Nilai CR pada penelitian ini yaitu, Persepsi Pengembangan (PP) terrhadap Sikap (SK) sebesar 9.215, Persepsi Konsep (PK) terhadap Sikap (SK) sebesar 3,531, dan Sikap (SK) terhadap Minat (MN) sebesar 14.138. Hal ini menunjukkan bahwa uji normalitas secara mayoritas tidak terdistribusi normal karena nilai CR berada di atas 1.91. Meski normalitas tidak terpenuhi, data dalam penelitian ini tetap dianalisis karena data merupakan data primer dari responden atas pernyataan dalam kuesioner. Selain itu penelitian ini mengguanakan teknik Maximum Likelihood untuk menghasilkan estimasi yang kuat meskipun data tidak terdistribusi normal. (Purwanto, 2002:159).

\section{Uji Outlier}

Data penelitian dikatakan outlier jika nilai df $>4$. Uji outlier dapat dilakukan dengan menambah atau mengurangi data yang bersifat ekstrim yang memiliki nilai df di atas 4. Setelah dilakukan uji outlier, menunjukkan bahwa nilai df yang di atas 4 berjumlah 100 data. Hal ini mengharuskan sebanyak 100 data dibuang, akhirnya data yang 
semula berjumlah 435 berkurang menjadi 335 dan tentunya karakteristik responden juga berubah.

Uji Model (Goodness of Fit)

Tabel 3. Kriterian Goodness of Fit

\begin{tabular}{llll}
\hline Indeks Goodness of Fit & $\begin{array}{c}\text { Cut of } \\
\text { Value }\end{array}$ & $\begin{array}{c}\text { Model } \\
\text { Penelitian }\end{array}$ & Keterangan \\
\hline Absolute $f t$ measure & & & \\
Chi-square & Kecil & 467,995 & Baik \\
RMSEA & $<0.08$ & 0,064 & Baik \\
GFI & $>0.90$ & 0,894 & Marginal \\
Intcremintal ftit measures & & & \\
AGFI & $>0.90$ & 0,864 & Marginal \\
CFI & $>0.95$ & 0,961 & Baik \\
TLI & $>0.95$ & 0,955 & Baik \\
Parcimonious ftit measures & & & \\
CMIN/df & $\leq 5.00$ & 2,364 & Baik \\
\hline
\end{tabular}

Berdasarkan keseluruhan pengukuran goodness of ft pada tabel 3 model yang diajukan pada penelitian ini sudah baik karena nilai ChiSquare, RMSEA, CFI, TLI, CMIN/df, telah memenuhi kriteria fit, serta nilai GFI dan AGFI hampir memenuhi kriteria.

\section{Uji Hipotesis}

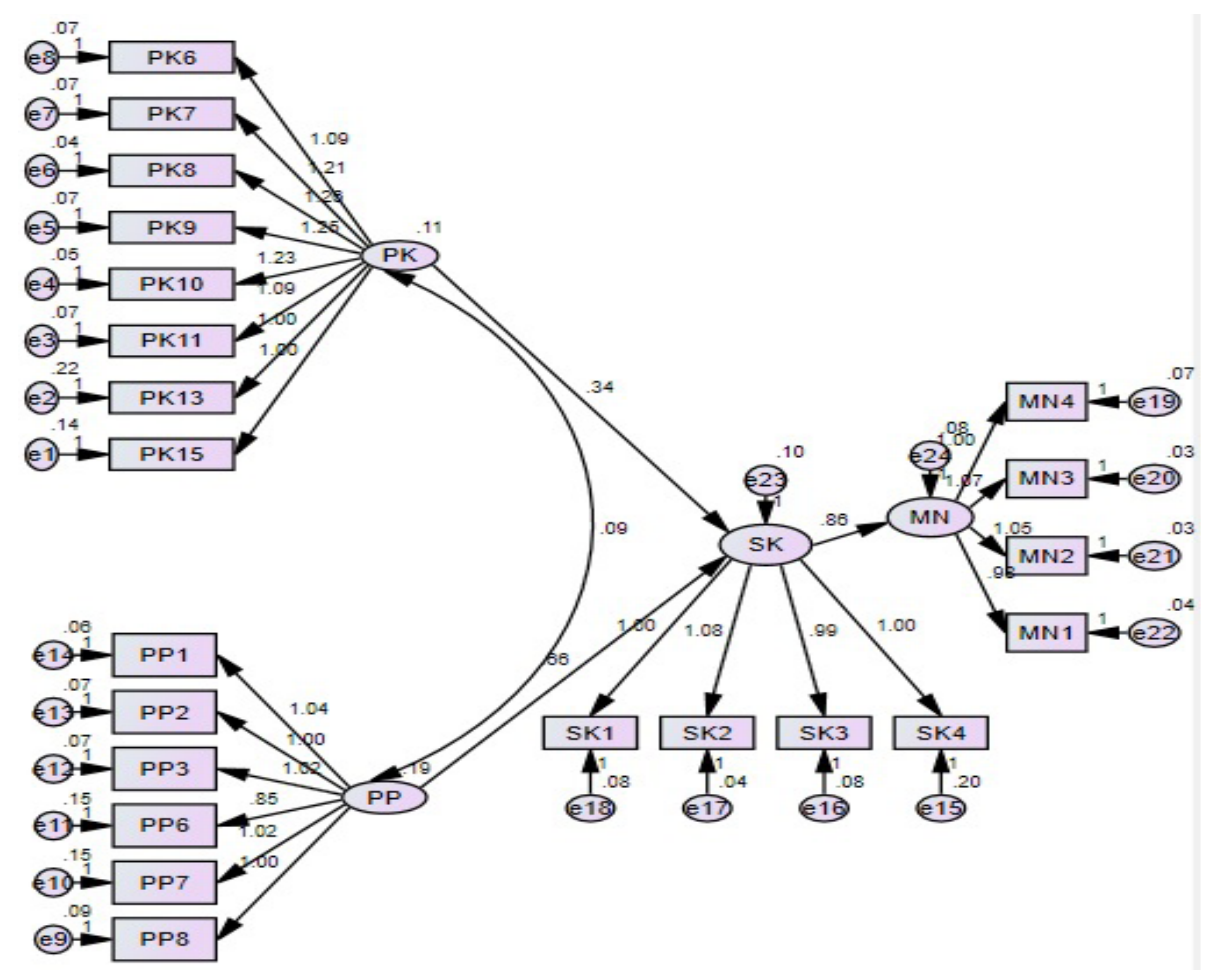


Gambar 4. Model Penelitian

Tabel 4. Nilai Loading dan Signifikansi Hubungan Struktural Antar Konstruk

\begin{tabular}{lccccc}
\hline Pengaruh & $\begin{array}{l}\text { Nilai } \\
\text { Estimate }\end{array}$ & $\begin{array}{l}\text { Critical } \\
\text { Ratio }\end{array}$ & $\begin{array}{l}\text { Standardized } \\
\text { Regression } \\
\text { Weight }\end{array}$ & P-Value & Keterangan \\
\hline $\mathrm{PP} \rightarrow \mathrm{SK}$ & 0,689 & 9,215 & 0,075 & 0.000 & Signifikan \\
$\mathrm{PK} \rightarrow \mathrm{SK}$ & 0,284 & 3,531 & 0,080 & 0.000 & Signifikan \\
$\mathrm{SK} \rightarrow \mathrm{MN}$ & 0,853 & 14,138 & 0,060 & 0.000 & Signifikan \\
\hline
\end{tabular}

Tabel 5 dapat dilihat hasil uji regression weight yang dapat menjelaskan koefisien pengaruh antara variabel terkait. Hasil dari analisis regression weight menunjukkan bahwa:

\section{Pengaruh Persepsi terhadap Sikap Masyarakat akan Pariwisata Halal}

Hasil uji statistik menunjukkan parameter estimasi nilai koefisien standardized regression weight diperoleh sebesar 0,080 dan nilai CR 3,531, hal ini menunjukkan bahwa terdapat pengaruh positif dari persepsi konsep terhadap sikap. Artinya semakin baik persepsi konsep masyarakat mengenai pariwisata halal maka akan meningkatkan sikap positif masyarakat terhadap pariwisata halal di DIY. Pengujian hubungan kedua variabel tersebut menunjukkan nilai probabilitas $0.000(p<0.05)$, sehingga $\mathrm{H}_{1}$ dalam penelitian ini terdukung.

Menurut konsep GMTI, terdapat tiga kriteria pariwisata halal, yakni destinasi ramah keluarga, fasilitas, dan kesadaran kehalalan serta pemasaram destinasi. Hasil penelitian menunjukkan bahwa responden mempunyai persepsi konsep terhadap pariwisata halal yaitu menganggap bahwa pariwisata halal menyediakan fasilitas beribadah dan fasilitas umum. Fasilitas beribadah seperti mushola yang bersih, selalu mengumandangkan adzan, serta kamar mandi dan tempat wudhu yang terpisah antara laki-laki dan perempuan. Fasilitas umum seperti tempat parkir dan tempat sampah yang memadai. Dengan persepsi konsep masyarakat seperti itu, akan mempengaruhi sikap masyarakat untuk memilih pariwisata halal yang sesuai persepsi mereka untuk dikunjungi. Bahwasannya ketika pariwisata halal menyediakan fasilitas beribadah dan fasilitas umum yang sesuai dengan persepsi masyarakat, maka masyarakat akan engunjungi pariwisata halal.

\section{Pengaruh Persepsi Pengembangan terhadap Sikap Masyarakat akan Pariwisata Halal}

Parameter estimasi nilai koefisien standardized regression weight diperoleh sebesar 0,075 dan nilai CR 9,215, hal ini menunjukkan bahwa terdapat pengaruh positif dari persepsi pengembangan terhadap sikap. 
Artinya semakin baik persepsi pengembangan masyarakat mengenai pariwisata halal maka akan meningkatkan sikap positif masyarakat terhadap pariwisata halal di DIY. Pengujian hubungan kedua variabel tersebut menunjukkan nilai probabilitas $0.000(p<0.05)$, sehingga $\mathrm{H}_{2}$ dalam penelitian ini terdukung.

Hasil penelitian menunjukkan bahwa responden mempunyai persepsi pengembangan terhadap pariwisata halal yaitu menganggap bahwa pariwisata halal jika dikembangan di DIY akan membuka peluang kerja bagi masyarakat, meningkatkan pendapatan penduduk, mengurangi kejahatan dan masalah sosial, serta meningkatkan reputasi dan memperkuat budaya yang ada di Yogyakarta. Hal ini menunjukkan bahwa dengan persepsi pengembangan masyarakat yang positif, akan mempengaruhi sikap masyarakat secara positif untuk turut serta mengembangakan pariwisata halal di Yogyakarta.

\section{Pengaruh Sikap terhadap Minat Masyarakat akan Pariwisata Halal}

Parameter estimasi nilai koefisien standardized regression weight diperoleh sebesar 0,060 dan nilai CR 14,138, hal ini menunjukkan bahwa terdapat pengaruh positif dari sikap terhadap minat. Artinya semakin baik sikap masyarakat mengenai pariwisata halal maka akan meningkatkan minat masyarakat terhadap pariwisata halal di DIY. Pengujian hubungan kedua variabel tersebut menunjukkan nilai probabilitas $0.000(p<0.05)$, sehingga $\mathrm{H}_{3}$ dalam penelitian ini terdukung.

Hasil penelitian menunjukkan bahwa responden mempunyai sikap yang positif terhadap pariwisata halal dengan memilih pariwisata halal sebagai destinasi berlibur karena responden menganggap bahwa pariwisata halal penting bagi responden. Dengan sikap responden seperti itu, akan mempengaruhi minat responden secara positif untuk mengetahui lebih dalam tentang pariwisata halal, berniat akan mengunjungi pariwisata halal di masa yang akan datang, serta akan merekomendasikan lokasi wisata halal kepada orang lain.

Hasil penelitian menyatakan bahwa seluruh hipotesis dalam penelitian ini terdukung, artinya minat dipengaruhi oleh sikap, sikap dipengaruhi oleh persepsi konsep dan persepsi pengembangan. Hasil penelitian ini menunjukkan bahwa teori Ajzen mengenai TPB telah terkonfirmasi.

\section{KESIMPULAN}

Berdasarkan hasil pembahasan dalam penelitian menyatakan bahwa keseluruhan hipotesis yang dirumuskan dapat diterima. Sehingga dapat diartikan bahwa seluruh hipotesis yaitu $\mathrm{H}_{1}, \mathrm{H}_{2}, \mathrm{H}_{3}$, menunjukkan hasil yang signifikan. Hasil penelitian menunjukkan bahwa terdapat hubungan atau pengaruh secara positif antara persepsi, sikap, dan minat masyarakat terhadap pariwisata halal. Artinya semakin baik 
persepsi masyarakat akan semakin baik pula sikap masyarakat terhadap pariwisata halal. Begitu pula semakin baik sikap masyarakat terhadap pariwisata halal maka akan semakin tinggi minat masyarakat terhadap pariwisata halal. Selain itu, hasil analisis menunjukkan bahwa masyarakat memiliki persepsi jika pariwisata halal adalah pariwisata yang terdapat fasilitas beribadah seperti musala yang bersih dan selalu mengumandangkan adzan, serta tempat wudhu dan kamar mandi yang terpisah antara laki-laki dan perempuan.

Pariwisata halal idealnya telah memenuhi kriteria GMTI. Namun, berdasarkan hasil penelitian menunjukkan bahwa persepsi masyarakat terhadap pariwisata halal lebih kepada pengembangan fasilitasnya. Selain itu, pariwisata halal juga memiliki benefit bagi masyarakat seperti membuka peluang kerja, meningkatkan pendapatan penduduk, membantu perkembangan sektor usaha lain, mengurangi kejahatan social, memperkuat budaya dan meningkatkan citra DIY.

\section{SARAN}

Pemerintah hendaknya lebih memprioritaskan untuk mengembangan fasilitas pariwisata halal karena persepsi masyarakat DIY terhadap pariwisata halal terletak pada fasilitasnya. Hal ini didukung oleh penelitian Yousaf et.al (2018:441) yang menyatakan bahwa Malaysia, Indonesia, UEA, dan Turki menempati 4 tempat teratas dalam indeks yang sama dalam hal fasilitas yang sesuai dengan agama yang diberikan kepada para pelancong muslim karena termasuk dalam negara mayoritas muslim, serta Indonesia memiliki standar fasilitas yang tinggi terhadap pariwisata halal. Dengan demikian, perlu meningkatkan fasilitas dalam pariwisata halal di DIY. Selain itu, Pemerintah perlu strategi inkubator bisnis untuk mensosialisasikan dan mengembangkan pariwisata halal di DIY. Hal ini didukung dalam penelitian Hernandez et.al (2016: 723) yang berfokus pada inkubator bisnis yang membahas dimensi keberlanjutan sosial dan ekonomi di negara berkembang. Inkubator bisnis dianggap sebagai mekanisme penting untuk pembangunan berkelanjutan karena melibatkan para pemangku kepentingan dan kegiatan yang relevan untuk saling berinteraksi.

\section{DAFTAR PUSTAKA}

Ajzen, Icek. 1991. The Theory of Planned Behaviour. Amerika Serikat: University of Massachusetts at Amherst.

Ajzen, Icek. 2005. The Theory of Planned Behaviour. Amerika Serikat: University of Massachusetts at Amherst.

Alim, Haidar Tsany dan Andi Okta Riansyah, dkk. (t.t.) "Analisis Potensi Pariwisata Syariah dengan mengoptimalkan Industri Kreatif di Jawa Tengah dan Yogyakarta." Jurusan Akuntansi, Fakultas Ekonomika dan Bisnis, Universitas Diponegoro, Semarang. 
Anonim. 2016. GMTI Jadi Acuan Kriteria Wisata Halal." Dalam Republika. co.id, https://republika.co.id/berita/koran/financial/16/04/20/ o5xd0810-gmti-jadi-acuan-kriteria-wisata-halal, diakses 23 Februari 2019.

Anonim. 2016. Statistik Profil Wisatawan Nusantara Tahun 2016. Jakarta Pusat: Badan Pusat Statistik.

Anonim. 2017. "Ketua Umum MES Himbau Yogyakarta Kembangkan Wisata Syariah." Dalam Ekonomi Syariah

Anonim. 2017. Statistik Kepariwisataan 2017 Daerah Istimewa Yogyakarta. Daerah Istimewa Yogyakarta: Dinas Pariwisata.

Anonim. 2018. "Lombok, Aceh, dan Jakarta Destinasi Pariwisata Halal Utama." Dalam Republika.co.id,

Antara. 2018. "Pertumbuhan Pariwisata Indonesia Peringkat 9." Dalam Tempo, https://travel.tempo.co/read/1139099/pertumbuhanpariwisata-indonesia-peringkat-9-di-dunia/full\&view=ok pada , 20 Februari 2019.

Awwal, M. Alfaridho et.al. 2018. Sharia Economics Edugame (SEE): "Alternatif pengembangan Pemahaman Literasi Keuangan Syariah". Jurnal Studi Agama dan Masyarakat. Vol. 14, No. 1.

Ginting, Dahlia Br. 2009. "Structural Equation Model (SEM)." Dalam Jurnal Media Informatika, Vol. 8, No. 3. Sekolah Tinggi Manajemen Informatika dan Komputer LIKMI.

Hernandez, Roberto et.al. 2016. "A conceptual approach for business incubator interdependencies and sustainable development." Dalam Agriculture and Agricultural Science Procedi, Vol 8, hlm. 718 - 724, https://doi.org/10.1016/j.aaspro.2016.02.054.

http://www.ekonomisyariah.org/6595/ketua-umum-mes-himbauyogyakarta-kembangkan-wisata-syariah/, diakses 19 Februari 2019.

https://m.republika.co.id/amp/pjmpxk320\&ved=2ahUKEwi, diakses 23 Februari 2019

Kambuaya, Carlos. 2015. "Pengaruh Motivasi, Minat, Kedisiplinan dan Adaptasi Diri Terhadap Prestasi Belajar Siswa Peserta Program Afirmasi Pendidikan Menengah Asal Papua Barat di Kota Bandung." Dalam Social Work Jurnal, Volume 5, No. 2, ISSN:2339-0042.

Kementrian Pariwisata. http://www.kemenpar.go.id.

Listyana, Rohmaul dan Yudi Hartono. 2015. "Persepsi dan Sikap Masyarakat Terhadap Penanggulangan Jawa dalam Penentuan Waktu Pernikahan (Studi Kasus Desa Jonggrang Kecamatan Barat Kabupaten Magetan Tahun 2013)." Dalam Jurnal Agastya, Vol. 5 No. 1.

Lonely Planet. 2019. "Best in Travel 2019." Dalam New York :Lonely Planet, ISBN 9781787017658.

Mulyana, Aina ... Soleh Hidayat dan Sholih. 2013. "Hubungan Antara Persepsi, Minat, dan Sikap Siswa dengan Hasil Belajar Siswa Dalam 
Pembelajaran Pkn." Dalam Jurnal Pendidikan dan Kebudayaan Vo. 19 No. 2.

Nurkhan. 2005. "Pengaruh Latar Belakang Pekerjaan Orang Tua Terhadap Minat Berwirausaha Siswa Kelas II Program Keahlian Teknik Mekanik Otomotif SMK Negeri 1 Tulis Batang Tahun Ajaran 2005/2006." Skripsi. Semarang: Universitas Negeri Semarang.

Oktradisa, Ahwy. 2015. "Analisis Persepsi Leadership dan Kewirausahaan dalam Mencapai Visi Teacherprenuership dan Entrepreneurship (Studi Kasus Mahasiswa Fakultas Agama Islam Universitas Muhammadiyah Magelang)". Dalam Cakrawala, Vol. X, No. 1.

Pratiwi, Fuji. 2016. "GMTI Jadi Acuan Kriteria Wisata Halal." Dalam Republika.co.id, https://republika.co.id/berita/koran/ financial/16/04/20/o5xd0810-gmti-jadi-acuan-kriteria-wisata-halal, diakses 23 Februari 2019.

Purwanto, B.M. 2002. "The Effect of Salesperson Stress Factors on Job Performance". Dalam Jurnal Ekonomi dan Bisnis Indonesia, Vol. 17, No. 22

Reinartz, Wemer. 2009. "An Empirical Comparison of the Efficacy of Covariance-Based and Variance-Based SEM." Dalam Interen J. of Research in Marketing, https://doi.org/10.1016/j. ijresmar.2009.08.001.

Riza, Alex Fahrur. 2017. "Skeptisme Nasabah Terhadap Klaim Syariah dari Perbankan Syariah." Dalam Jurnal Al-Bayan, Vol. 22, No. 31.

Salman Yousaf et. al. 2018. Halal Culinary and Tourism Marketing Strategies on Government Websites: A Preliminary Analysis. Dalam. Tourism Management. Vol. 68 hlm. 423-443, www.elsevier.com/ locate/tourman.

Santoso, A. 2011. "Serat Pangan (Dietary Fiber) dan Manfaatnya Bagi Kesehatan." Dalam Skripsi, Jurusan Teknologi Hasil Pertanian, Fakultas Teknologi Pertanian, Unwidha Klaten.

Sarwono, Sarlito W. 2009. Pengantar Psikologi Umum. Jakarta: Rajawali Pers.

UNWTO. 2016. Tourism Highlights, 2016 Edition. Madrid:World Tourism Organization (UNWTO).

Wahyuni, Dewi Urip. 2008. "Pengaruh Motivasi, Persepsi dan Sikap Konsumen Terhadap Keputusan Pembelian Sepeda Motor Merek "Honda" di Kawasan Surabaya Barat." Dalam Jurnal Manajemen dan Kewirausahaan, Vol.10, No. 1.

Waluyo, Minto. 2016. "Mudah cepat Tepat Penggunaan Tools AMOS dalam Aplikasi (SEM)." ISBN 978-6029-372960. 